\title{
A Feasibility Analysis of Photovoltaic Solar Power for Small Communities in Ireland
}

\author{
Enda Flood, K. McDonnell, F. Murphy and G. Devlin*
}

Biosystems Engineering Department, University College Dublin, Belfield, Dublin 4, Ireland

\begin{abstract}
Photovoltaic power generation is one of the cleanest sources for producing renewable energy, however to date its up take on the Irish renewable energy market has been extremely low. Through research carried out on regions where these technologies are widely used and developed, this project investigates the feasibility of using photovoltaic systems to generate power under Irish climatic conditions. This involved a comparative investigation between solar insolation in Ireland and in regions currently using Photovoltaic systems. This projects main aim was to identify if photovoltaic systems were a feasible source of power generation for a sustainable community of 130 eco-friendly homes based on the fact that they are built to B1 energy rating standards. B1 implies an energy use of between $75 \mathrm{kwh} / \mathrm{m}^{2} / \mathrm{yr}$ and $100 \mathrm{kwh} / \mathrm{m}^{2} / \mathrm{yr}$. Results showed that houses of $140 \mathrm{~m}^{2}$ have a PV area requirements ranging from $20 \mathrm{~m}^{2}-26 \mathrm{~m}^{2}$, while the larger live/work units of $195 \mathrm{~m}^{2}$ have an area requirement of $27 \mathrm{~m}^{2}-36 \mathrm{~m}^{2}$. While the communal solar park has an area requirement of $2665 \mathrm{~m}^{2}-3553 \mathrm{~m}^{2}$ without spacing, this however will differ when space requirements are calculated to prevent overshadowing. The results obtained prove that such systems are feasible, however may be dependent on governmental support or grants. The installation of such a system would not only provide benefits to the members of this eco-village through production of on-site energy, but also to national legislation relating to reduced $\mathrm{CO}_{2}$ emissions and increases in the percentage share of renewables in gross national electricity consumption. The results suggest that this system could produce between 1431000 - $1908000 \mathrm{kWh}$ per year, enough to sufficiently supply the community, while producing excess energy for three-quarters of the year, while displacing between $283338-377784 \mathrm{~kg} / \mathrm{CO}_{2} / \mathrm{yr}$.
\end{abstract}

Key Words: Solar PV, renewable technologies, building energy ratings, eco village design and carbon footprinting.

\section{INTRODUCTION}

This study aims to investigate the feasibility of using photovoltaic (PV) solar generation as a means of supplying a community, which aims to exist in a fully sustainable manner, with sufficient electric power. To complete this investigation, a hypothetical investigation will be conducted on the planned eco-village of Cloughjordan, Co. Tipperary, Ireland, which when fully completed will consist of 130 environmentally constructed friendly homes. This investigation will be carried out using secondary data relating to PV array and solar technologies, data collected on site relating to energy demands and community power requirements and also data obtained via Geographic Information Systems relating to solar insolation for this site. The over all objectives are to identify if the use of PV panels is a feasible system when all cost and expenditures are included. Also under investigation will be the possibility of exporting excess generated power to the national grid and the benefits this may produce for the community. Under investigation will be the use of a centralised solar park, to act as a community mini grid supplying homes on a metered basis. This will take in to account the energy demands of the houses in this community and identify the requirements in land area for such a project. Carbon dioxide reductions, due to production of renewable

*Address correspondence to this author at the Biosystems Engineering Department, University College Dublin, Belfield, Dublin 4, Ireland; Tel +353 1716 7418; Fax:+353 1716 7415; E-mail: ger.devlin@ucd.ie energy will also come under investigation, with the report highlighting how much carbon dioxide could be offset through development of such a project.

\section{BACKGROUND}

The Cloughjordan eco-village is the first of its type in Ireland. This village has been under plans since 1999, when a group of like-minded environmentalist came together and proposed the idea of a sustainable village community. The site, adjacent to the typical Irish village of Cloughjordan, was chosen from more than 40 sites. Preference was given to this site, as there are already a number of key specifics in existence there. Firstly there is the access to the DublinLimerick railway line, there is also existing services in the original village, allowing for community integration from the onset. The quality of the farmland in this region was another key factor in for choosing this site. The planned sustainable village is set out over a 67 -acre site, which has been roughly divided into three equal areas. One-third of the site is residential, one-third for woodland and one-third for food production. The new residential area extends from the original main street of Cloughjordan, integrating the eco-village into the original village. This integration allows for the woodland and food production areas to blend into the surrounding countryside, with little environmental and aesthetic impacts.

\section{Eco Village Design}

This new residential area, when complete, will comprise of 130 houses, constructed with different materials and 
Table 1. Overshading Factors, (SEI, 2008)

\begin{tabular}{|c|c|c|}
\hline Overshading & \% of Sky Blocked by Obstacles & Overshading Factor \\
\hline \hline Heavy & $>80 \%$ & 0.50 \\
\hline Significant & $>60 \%-80 \%$ & 0.65 \\
\hline Modest & $20 \%-60 \%$ & 0.80 \\
\hline None or little & $<20 \%$ & 1.0 \\
\hline
\end{tabular}

methods. To aid in the process of adding variety and complexity to the village's new residential sector, all houses are designed by different architects. The overall master plan for the residential area is to maximise solar gains, while creating a link to the existing village. All buildings on site must adhere to the village's eco-charter, which has been developed by members of the village. This charter states that buildings should be highly insulated, make use of passive gains and renewable energy, minimise potable water consumption, reduce construction waste and use low embodied building materials. The homes currently under construction, and those already built have all employed various building methods and materials, including timber frame systems, various forms of hemp-lime construction and use of durisol block work, which consists of a mix of cement and wood fibre, to reduce a buildings overall carbon foot print. Adhering to the village's charter, all homes currently inhabited are highly insulated, and have a minimum Building Energy Rating Certificate of B1. A number of these homes have gone beyond SEI requirements for achieving Passive House standards, even though only one has been certified by the Passivhaus Institut. This super insulation of homes aims to further reducing their overall energy demands.

A one Mega-Watt (MW) wood-chip district heating system will supply heat and hot water to all homes on site. This system consists of two 500 kilo-Watt $(\mathrm{kW})$ boilers, ran on wood-chip that will be grown in the village's woodlands and will heat water for a centralised 17,000 litre buffer tank. The district heating system was designed, supplied and installed by the Cork based company, Renewable Energy Management Service. This system comprises of nearly $4 \mathrm{~km}$ of Calpex pre-insulated piping, which will deliver water heated to around $60^{\circ} \mathrm{C}$ to an 800 litre super insulated buffer tank in each house. These insulated buffer tanks allow residents access to a constant supply of hot water preventing problems during peak demand. This also prevents the requirement of residents drawing hot water directly from the main supply, which would require that the system have a constant supply of hot water, therefore increasing the systems capacity. In addition to the $1 \mathrm{MW}$ boiler, a $506 \mathrm{~m}^{2}$ solar thermal array, will supplement heating demands, with the production of $480-$ 500 kilowatt-hours $(\mathrm{kWh}) / \mathrm{m}^{2} /$ year. It is believed that this array will sufficiently supply the community's hot water demand during the summer months.

\section{The Use Of Renewables For New House Design}

The use of Renewable Energy Systems (RES) has become a very important concept since the publication of the European Unions (EU) 2020 by 2020 package. This package, published in January 2008 proposes committing the EU to a $20 \%$ reduction in its greenhouse gas (GHG) emis- sions and to achieving a target of deriving 20\% of the EU's final energy consumption from RES, both by 2020 [1]. Campoccia, et al. [2] in 2008 stated that such a package would help the EU improve upon their measures of environmental protection and sustainable development, while also making it possible to reach Kyoto targets. Campoccia also identified the goals set out in this package as being of a challenging nature that can only be reached with an effective RES incentive based policy and with an improvement in the efficiencies of these RES. A report carried out by Nomisma Engeria, 2007, [3] identifies, from a list of six RES, wind and PV as having the highest growth rate in the period from 1997 to 2005, and identifies these two technologies as being the most important in contributing a significant share to future global renewable energies. With this in mind, this study aims to investigate the possibilities of PV systems under Irish climatic conditions, investigating if lower sunshine levels here, will have a reduced effect for PV renewable energies.

\section{SOLAR TECHNOLOGIES}

Currently there are three forms of solar technologies employed to harvest the sun's energy or insolation; these include Solar Passive, Solar Thermal and Solar Photovoltaic technologies. This study will investigate Solar PV technologies only. Solar insolation is an infinite and untimely free energy resource that when utilised via high-technology systems can be converted in to usable electricity. Solar insolation is recorded as kilowatt-hours per square meter $\left(\mathrm{kWh} / \mathrm{m}^{2}\right)$ (Energy, 2001), and includes both direct and indirect insolation reaching the earth's surface. Solar insolation provides approximately 10,000 times more energy to the earth's surface, than is consumed on an annual global basis. On average $1700 \mathrm{kWh} / \mathrm{m}^{2}$ is insolated to the earth per year [4]. Calculating the exact insolation for a given site can be difficult, due to the earth's rotating orbit around the sun, resulting in a changing angle of incidence between the solar insolation and that site on an hourly, daily and monthly basis [5]. Solar PV systems work on the basis of generating electric power by using semi conductor cells to convert solar insolation into electricity [6]. In Ireland, depending on location and solar insolation, a typical home may require between 3-5 solar panels of $1 \mathrm{~m}^{2}$ in size at $100 \%$ efficiency, to generate required power needs.

PV modules are available in different sizes ranging from 30 to $120 \mathrm{kWp} / \mathrm{m}^{2}$ (SEI, 2008) [7]. Overshading is defined by a SEI report (2008) [7], as the percentage of sky over the PV system that is blocked by an obstacle. This report categorises overshading as being heavy, significant, modest and none or little, with each category given an overshading factor to convert from peak output to mean output. See Table 


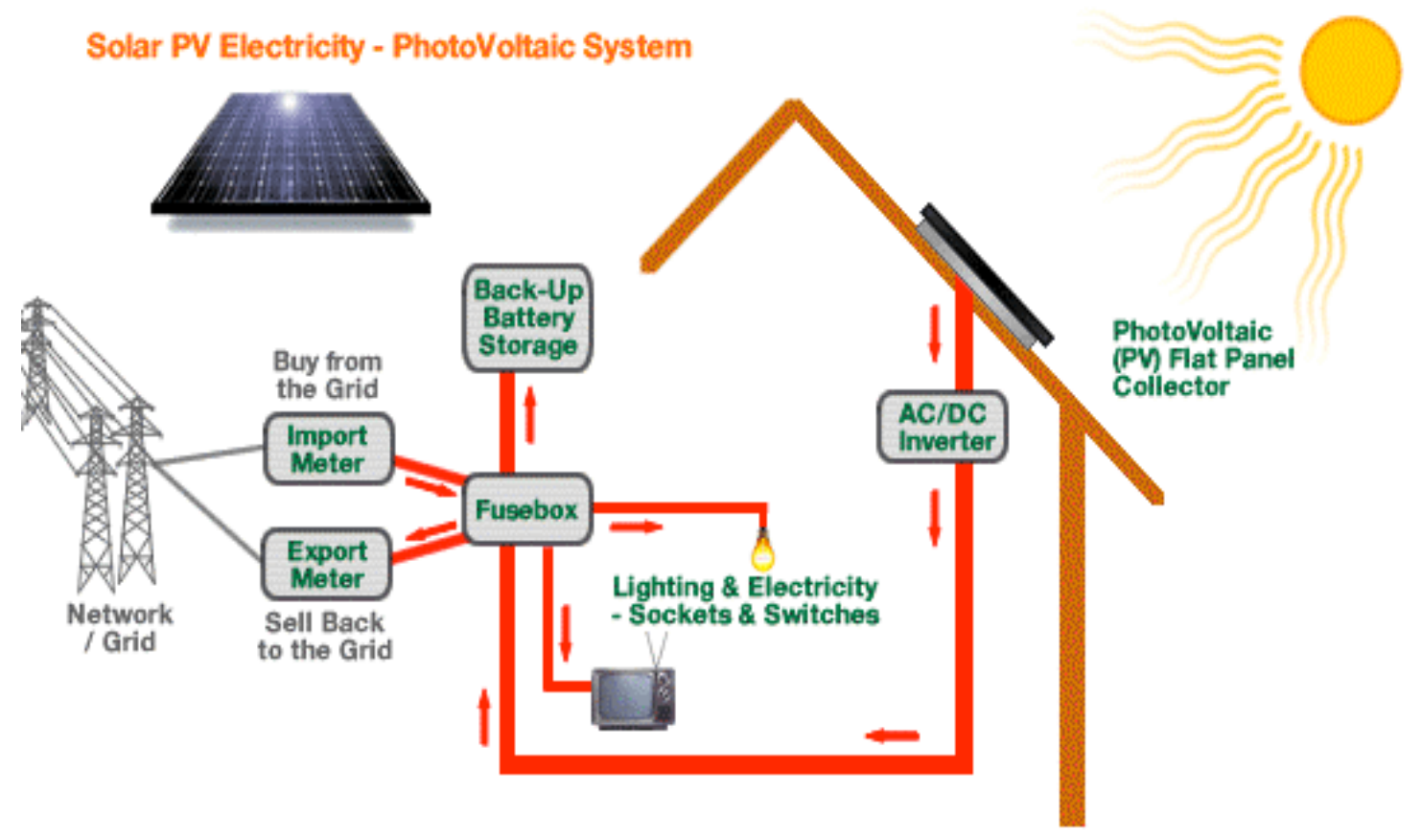

Fig. (1). Schematic example of a solar Photovoltaic system [13].

1 below for associated factors. Under Irish climatic condition a $1 \mathrm{kWp}$ system generally produce $860 \mathrm{kWh}$ per year [8].

\section{THE PHOTOVOLTAIC EFFECT}

As previously mentioned, PV systems use the photovoltaic effect to convert light energy into electric energy. This occurs when sunlight shining upon on the PV cell is absorbed, transferring the light's energy to electrons in the atoms of the PV cell. These charged electrons then separate from the atoms of the semiconductor material in the PV cell, to become part of the electrical current,[9]. Semiconductors create an electrical field, capable of forcing the newly generated electrical current to an external load. This electrical field is created due to the material used in the make up of the semiconductors. Semiconductors possess two layers of different material. One layer of n-type semiconductor material, which has an abundance of electrons and a negative electrical charge and one layer of p-type semiconductor material, which has an abundance of holes and a positive electronic charge. Bringing these two semiconductor materials together creates a p-n junction, which is responsible for generating the internal electrical field [10]. This electric field results in the electrons moving away from the positive semiconductor towards the negative surface, and become available to the electrical circuit. Cardon, et al., (1981) [11] explains that at the same time as the electrons are moving, the holes move in the opposite direction, towards the positive surface and await incoming electrons.

PV cells use mainly visible light in the wavelength spectrum of $400-780$ nanometres. It is a common misconception that PV systems operate only in direct sunlight, and are therefore not suitable for use in temperate regions. This however is not true, although PV generation is directly related to the intensity of light energy, where greater solar resources provide for greater electric potential. PV systems use daylight, not direct sunlight to generate electricity, and there- fore are suitable for use in areas of low solar radiation, such as Ireland. When calculating the potential energy generation for a specific site, it is important to assess the total yearly insolation for full potential. PV systems maybe incorporated into or on to existing buildings, such as pitched roofs, or may be built on to frames for installation on flat surfaces. A report carried out by Bonham-Carter, 2003, [12] in the UK found that arrays work best when facing either Southeast or Southwest and with an elevation of $30-40^{\circ}$, as this is the direction and elevation with optimum exposure to the sun's rays. Solar cells respond to sunlight that is either direct or diffused. Diffusion of light occurs when light rays are passed through or bounced of a rough surface, such as clouds. According to the US Department of Energy (2009) [9], diffuse sunlight accounts for between $10-20 \%$ of the total solar radiation, even on days with clear skies, $50 \%$ on partly cloudy days and $100 \%$ on cloudy days.

\section{PHOTOVOLTAIC POTENTIAL IN IRELAND}

Research carried out by Met Éireann indicates that Ireland normally receives between 1400 and 1700 sunshine hours per year [14]. This research states that, due to our geographical position off the north-west of Europe and close to the Atlantic low-pressure system, which tends to keep Ireland in humid cloudy conditions, Irish skies are clouded over more than $50 \%$ of the time. Data obtained by Met Éireann shows that May and June, with averages sunshine durations of between 5 and 6.5 hours per day, are the sunniest months, while December with an average of about one hour is the month with least sunshine. Sunshine hours vary through the length of the country, with the extreme south-east receiving most sunshine, averaging over 7 hours a day in early summer and almost two hours in December. This data also states that on average, over the year sunshine hours vary between 3.25 and 3.75 hours per day [14]. Future prediction modelling on solar insolation carried out by the 


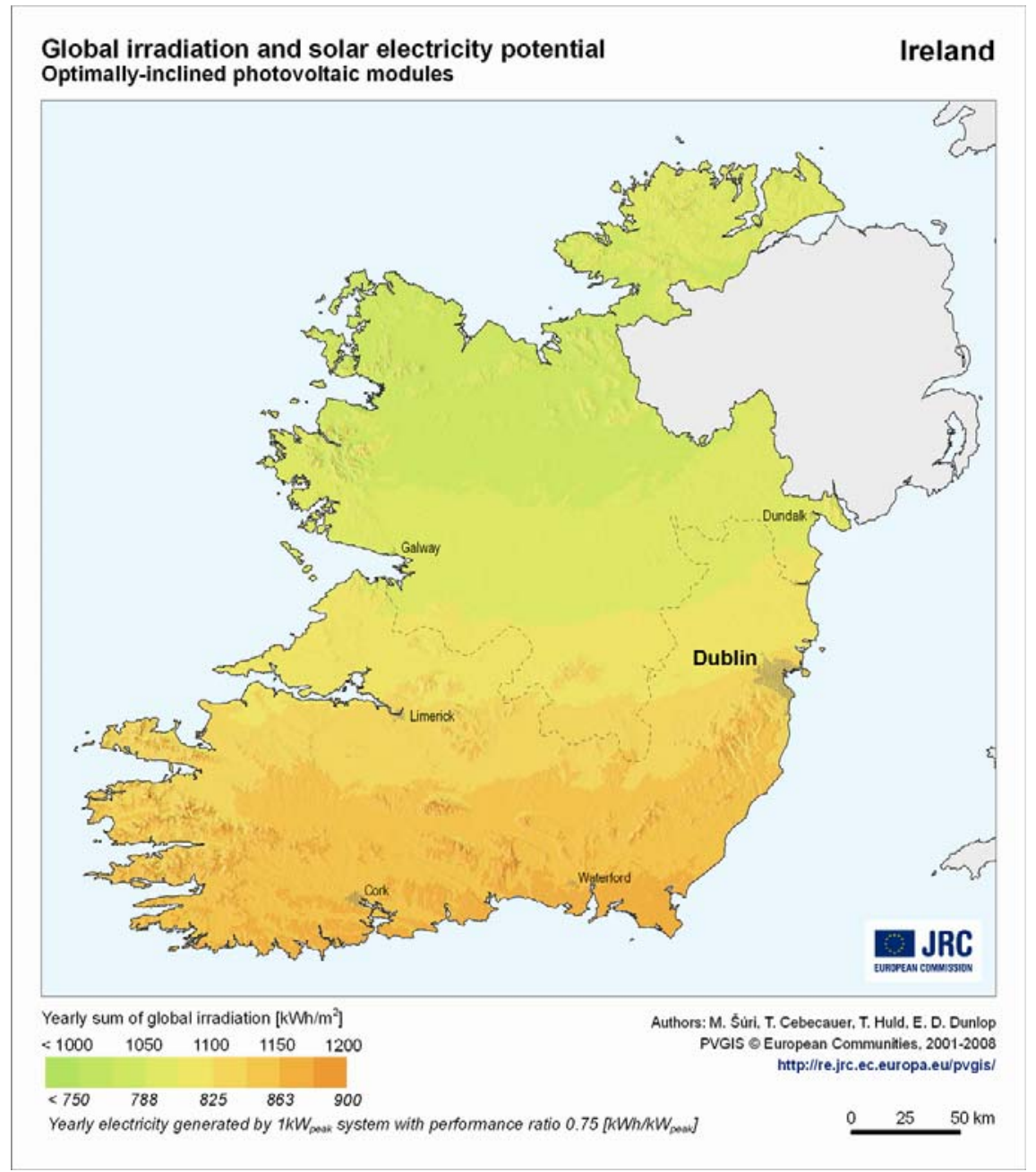

Fig. (2). Irish irradiation and solar electricity potential [17].

Community Climate Change Consortium in Ireland states that in 2055 and 2075, insolation levels will remain similar to what they are today. Data obtained from these modelling scenarios predicts that global warming will result in Ireland receiving $15 \%$ more rainfall during winter and a $20 \%$ reduction in summer rainfall, indicating that overall cloud cover is to reduce by $5 \%$ [15]. In comparison to sunshine hours received in some areas where PV technologies are currently operating, Ireland receives approximately 54\% less hours of sunshine per year, compared to Serpa, Alentejo, Portugal, an ideal location which receives 3,300 hours of sunlight a year. This area has an 11-megawatt (MW) power plant in operation since March of 2007, covering and area of 60 hectares. In comparison with northern Germany, where a 100-hectare, 40MW solar park is nearing competition, Ireland receives approximately $10 \%$ less sunshine hours only. This comparison is made with the climate of the Leipzig region of northern Germany, where sunlight hours range between 1.5 hours per day in December and 7.7 hours per day in June and average sunshine hours are 1726 hours of sunlight per year [16]. Fig. (2) below, which shows the yearly irradiation and solar electricity potential of Ireland. From Fig. (2) it can be taken that the area of interest in this report, the village of Cloughjordan, which is situated approximately 60 kilometres North of Limerick has the potential to produce electricity in the higher scale of 1100 to $1150 \mathrm{kWh} / \mathrm{m}^{2} /$ year.

The map in Fig. (2) shows the potential for solar electric generation for the whole of Ireland. The map indicates a potential generation of $1100-1150 \mathrm{kWh} / \mathrm{m} 2 / \mathrm{yr}$. for the area of interest in this report. Using this information and combining it with the energy demands of a typical Irish house, it can be concluded that $5 \mathrm{~m}^{2}$ of solar panelling would be required to generate all the power needs for a typical Irish home. This is if isolation was uniform throughout the year. This calculation is based on average yearly irradiation using solar panels with 0.75 efficiency and with a true South facing orientation.

A typical Irish domestic home (three bedroom, four person occupancy) requires approximately $5,590 \mathrm{kWh}$ of electricity per year [18]. Information obtained relating to the houses in Cloughjordan show that these houses, with an average size of $140 \mathrm{~m}^{2}$, and having a minimum BER of B1, will have an average yearly energy demand of $10500 \mathrm{kWh}$.

Ireland, having a seasonal variation of insolation will therefore have varying amounts of sunshine hours and insolation per month. This results in a need for greater area coverage during times of low insolation. The graph shown in Fig. (3) indicates the average monthly insolation for 


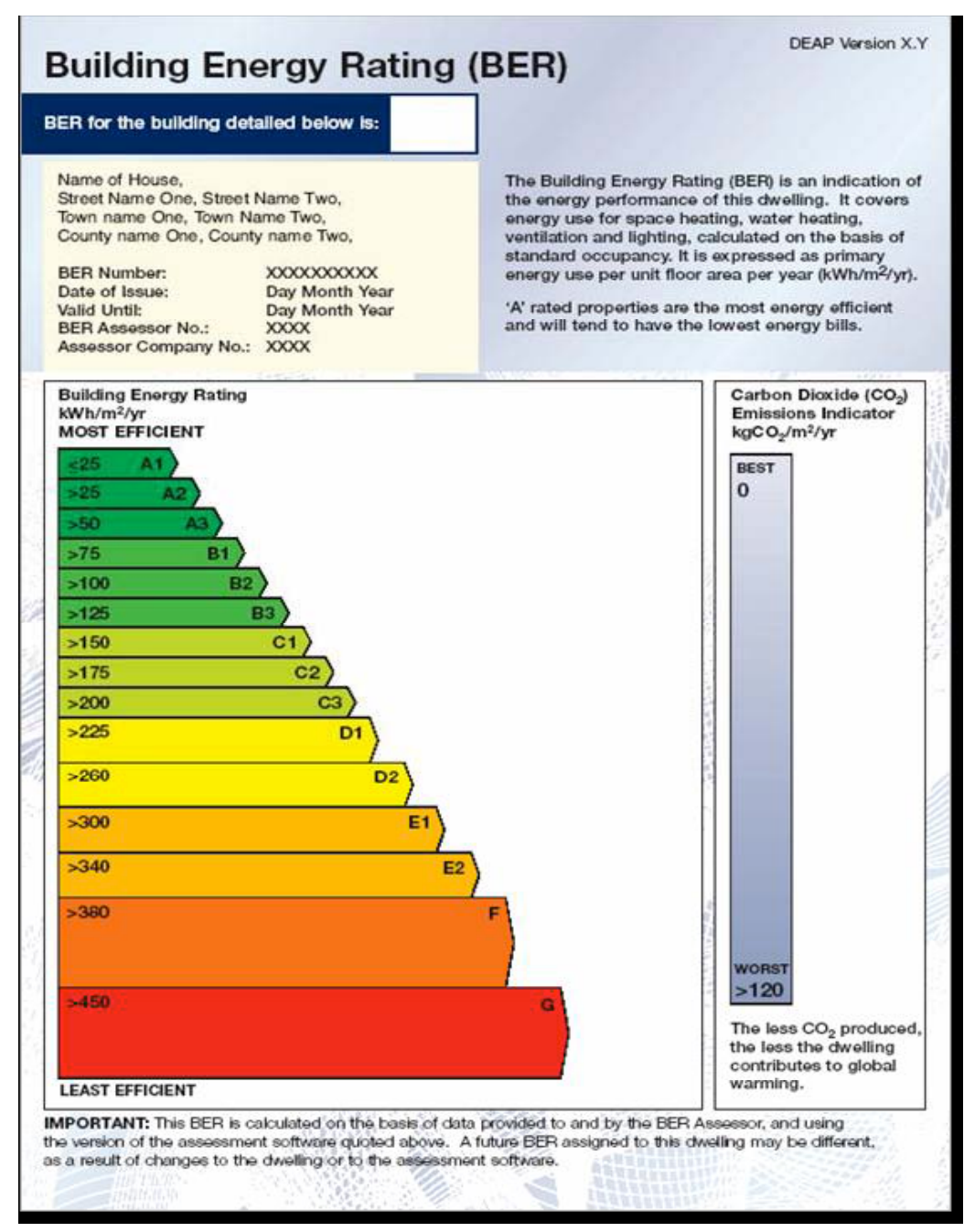

Fig. (3). BER Chart, with energy ranging demands and CO2 indicator [19].

Cloughjordan. These figures were calculated using European Commission, Photovoltalic Geographical Information System (PVGIS) online PV calculator [17]. For these calculations a crystalline silicone roof mounted system was used. This system has 0.84 efficiency, with a $35^{\circ}$ incline and $-2^{\circ}$ azimuth orientation (these figures were the optimum given by the calculator). Using these results and information obtained from a 2008 report, compiled by Sweeny et al., from The Department of Geography, NUI Maynooth, [20] along with information obtained from SEI, it has been possible to generate information on monthly energy demands of the typical Irish home. This information is conveyed in Fig. (4). By using this information in conjunction with that obtained from the solar irradiation maps in Fig. (2), along with information regarding energy demands for houses in the Cloughjordan development, it is possible to accurately estimate the space requirement per month needed to supply sufficient solar power to domestic homes.

Fig. (4) shows that in this area, as with the rest of Ireland insolation levels are greatest during summer month, reaching a high of $148 \mathrm{kWh} / \mathrm{m}^{2}$ in May and nearing this again in July. To supply sufficient power to meet a typical Irish home's energy demands during this period, with a 0.75 efficient system would require $2.39 \mathrm{~m}^{2}$ of solar panelling, based on results in Fig. (5) below. However, as previously stated, when power demands are greatest, insolation levels are lowest, requiring additional solar panels to meet demands. In this example the period of November to January has the lowest insolation levels, while also being the period of greatest demand. In this instance the same system would require $25.08 \mathrm{~m}^{2}$ of solar panelling, based on results in Fig. (5).

The graph shown above in Fig. (5). shows that there is a considerable variation in potential energy production through out seasonal pattern changes. In the case of homes in the Cloughjordan development, homes are operated in a more energy efficient manner. With space and heating requirements being met with RES and immersion heaters and electric showers have been banned, and where a number of residents have opted to forgo use of tumble dryers, to reduce energy demands. This has resulted in energy-friendly homes, which have power demands per square meter of area significantly less that of a typical Irish home. Therefore these houses, on an area to area comparison, should be able to meet their energy requirements with a smaller area of solar panelling per square meter area compared to typical Irish homes. 


\section{Average Monthly Energy Potential}

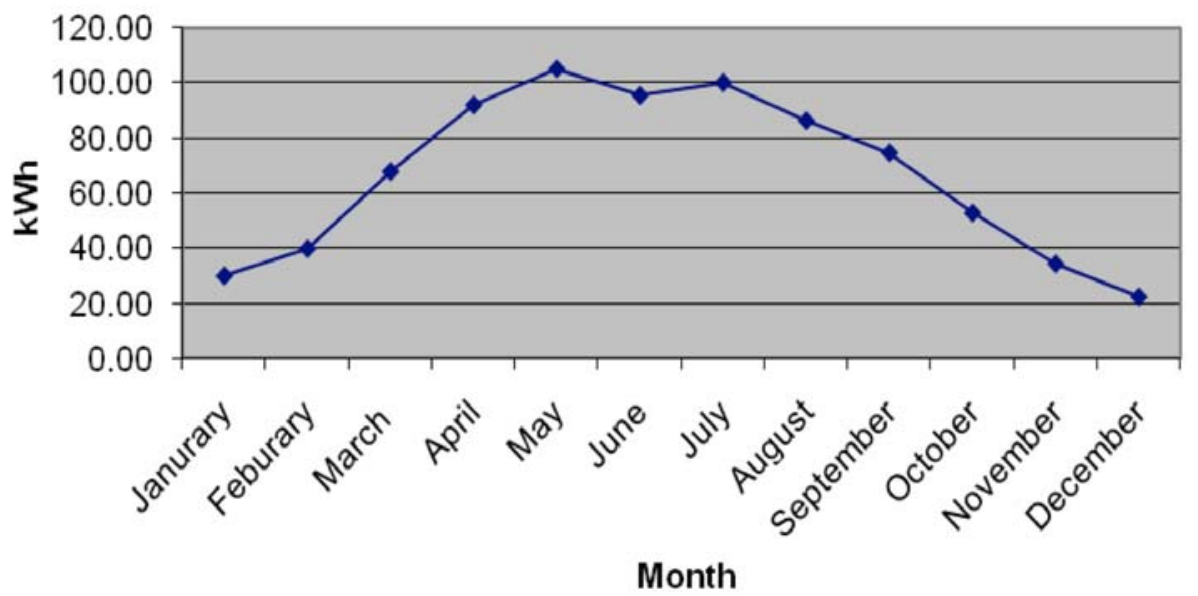

Fig. (4). Average monthly insolation for Cloughjordan, Co. Tipperary, Ireland [17].

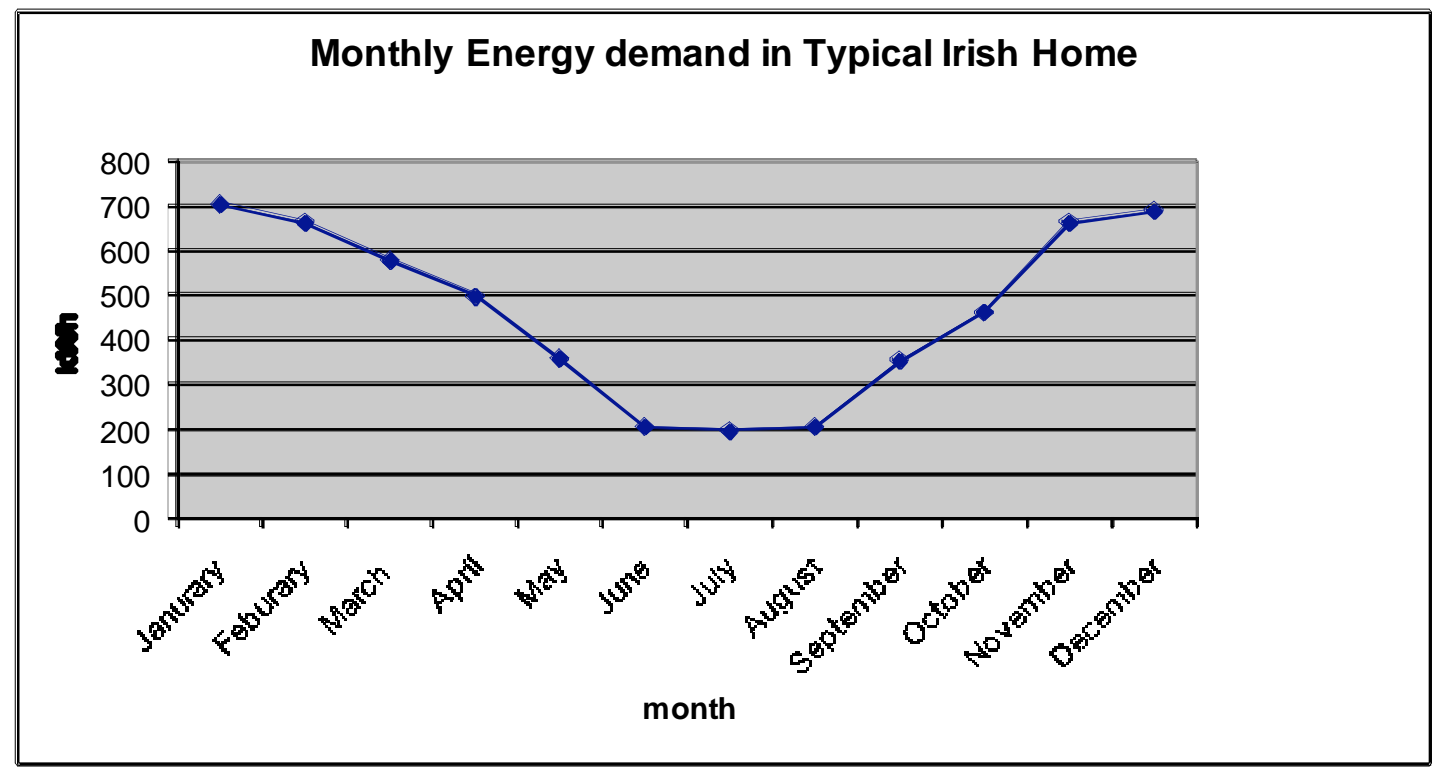

Fig. (5). Average monthly energy demand for typical Irish home.

In this instance, where by the community has sufficient land available there is the possibility to develop a central solar park, which could generate solar power for the entire community, or those wishing to avail of it. With individual houses being supplied with solar power on a metering basis, and pay for their individual usage. This may be useful in meeting the communities demands, as not all homes will be demanding power during the same period. A centralised solar park also leaves individuals free to install panels on their own properties. Developments like this already have been employed, however mainly large scale systems only. These include projects such as the Mojave Desert Solar Parks, located in the southwestern states of The United States, where insolation levels are among the highest in the world. Here Solar parks have been in operation since the early 1980's.Currently there are nine solar plants with a combines output of $354 \mathrm{MW}$. In this area insolation levels reach between $2190-2555 \mathrm{kWh} / \mathrm{m}^{2} / \mathrm{yr}$.

Similar projects have been constructed throughout Europe, with Germany, Spain and Portugal leading the way in term of project size. Germany is European forerunner in terms of solar technologies. As a result it is now in the process of completing the world's largest individual solar park, in Brandis, close to Leipzig in the Saxon region. This park, when complete will comprise of nearly 550, $000 \mathrm{PV}$ modules and cover an area of over one million square meters $(100 \mathrm{Ha})$, with an estimated production capacity of $40 \mathrm{MW}$. Calculation carried out for this area, using PVGIS calculations, identical to those carried out for Cloughjordan, yield very results similar. See Fig. (6), for results. These results suggest that insolation levels in Ireland are sufficient for producing large levels of PV generated power. 


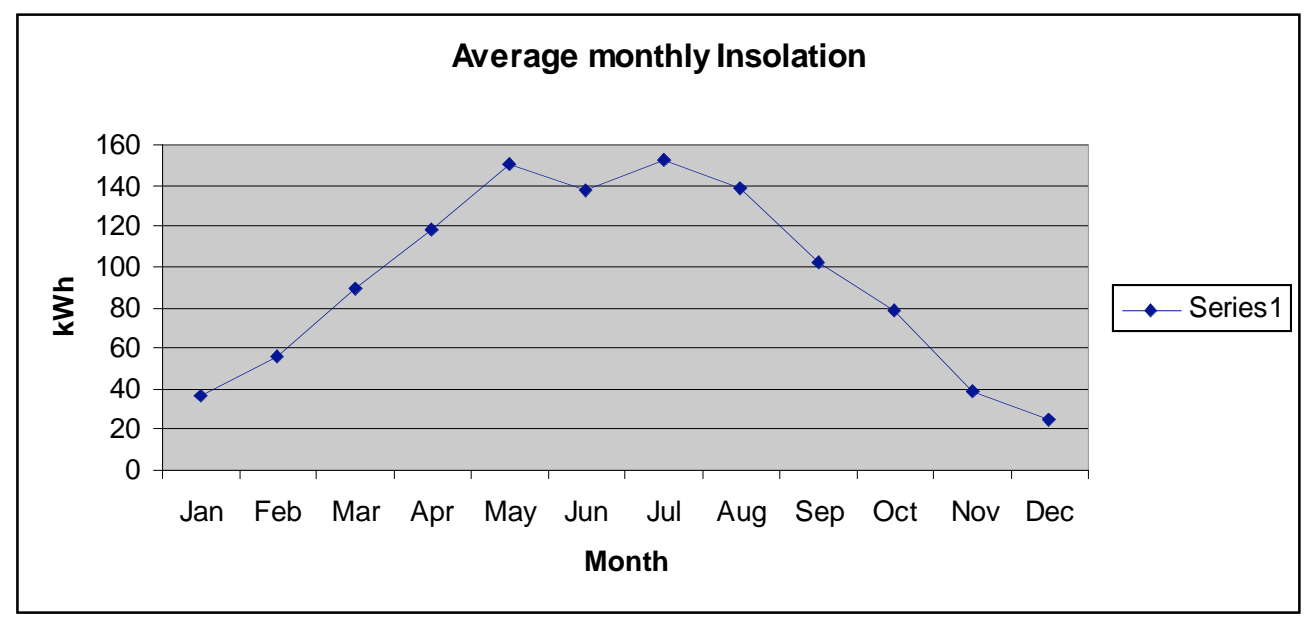

Fig. (6). Average monthly insolation for Brandis, Saxon, Germany (PVGIS 2009).

\section{BENEFITS OF PHOTOVOLTAIC SYSTEMS}

PV systems generate electricity from sunlight, an infinite and ultimately free energy resource, allowing for free electric generation, once initial capital cost of installation have been covered. Electricity generated via PV systems reduce the required amount of fossil fuel derived electricity, thus reducing GHG's and aiding in the global strive to reduce Climate Change. A study carried out by Alsema et al, 2006, [22] states that technologies developed for PV systems are considered to be extremely environmentally friendly, with modern PV system in Southern European locations having an energy pay-back period of 1.5-2 years, with pay-back periods increasing somewhat in areas of lower insolation. This study states that with future development in PV technologies, energy payback periods are likely to decrease. PV systems also offer a number of practical advantages:

- $\quad$ No moving parts, therefore requiring minimum maintenance or additional cost. There is no noise generated, eliminating such problems as noise pollution, which has been associated with other RES, such as wind turbines.

- No emissions or pollutants are released during production, making PV systems one of the cleanest RES. Allowing for national targets and legislation to be met.

- PV arrays or panels are easy to install or incorporate into buildings, either during construction or in retrofitting. PV systems can be used to add design features to a building, or may be used in place of an expensive building material, offering a similar finish at a lower cost.

- Improvements in production technologies have resulted in extremely reliable systems, with life expectancies of over 20 years. PV systems are generally guaranteed for between 10-20years. With BP Solar, a global solar company, offering guarantees of up to 25 years.

- PV systems produce on site electricity, therefore no wastes are incurred via transmission. These systems also allow isolated areas or buildings to operate electrical equipment, with use of stand-alone systems.

- Where extra electricity is produced, the producer can sell this back to the main grid, once a grid connection and export tariff scheme are place, thus generating an income from the system.

- Houses on the domestic market are more attractive, increasing the over all energy rating and property valuation.

\section{DISADVANTAGE OF PHOTOVOLTAIC SYSTEMS}

The one major disadvantage of PV systems is the initial cost factor of installing and setting up these systems, however this may be off set through available grants. Another disadvantage to these systems is that they are still relatively new to the domestic markets and therefore experience of their abilities and their use with engineers, architects and installers, is quite limited. However as these technologies enhance and people become more aware of them, consumer interest should help reduce both system disadvantages. A1ready there has been a large decrease in capital costs with some systems costs falling by nearly $25 \%$ over a period of eight years [23]. One further barrier to the growth of this system is the fact that these systems do not operate at night. This is particularly problematic in high northern and southern latitude countries; energy demand is highest in winter, while availability of solar energy is lowest, resulting in possible power shortages in winter months and power surpluses in summer months. This however can be overcome through connection to a main grid, whereby surplus summer power can be sold and additional power may be purchased in winter.

\section{SITE AND INSTALLATION REQUIREMENTS}

As this community's overall ethos is to live in a sustainable manner, where by a majority of raw material and a native heating and energy resource is provided on the 67 acre site, the siting of the proposed solar park is important for this ethos to continue. The site must not impede upon the general site, reducing the area allocated for food and timber production. However, such a site has a number of important requirements so that maximum power generation is achieved. These requirements are similar to those required when installing a PV system on a building's roof. The site should be south facing of have a slight south-east or south-west orientation and should not be overshadowed by and obstacles 


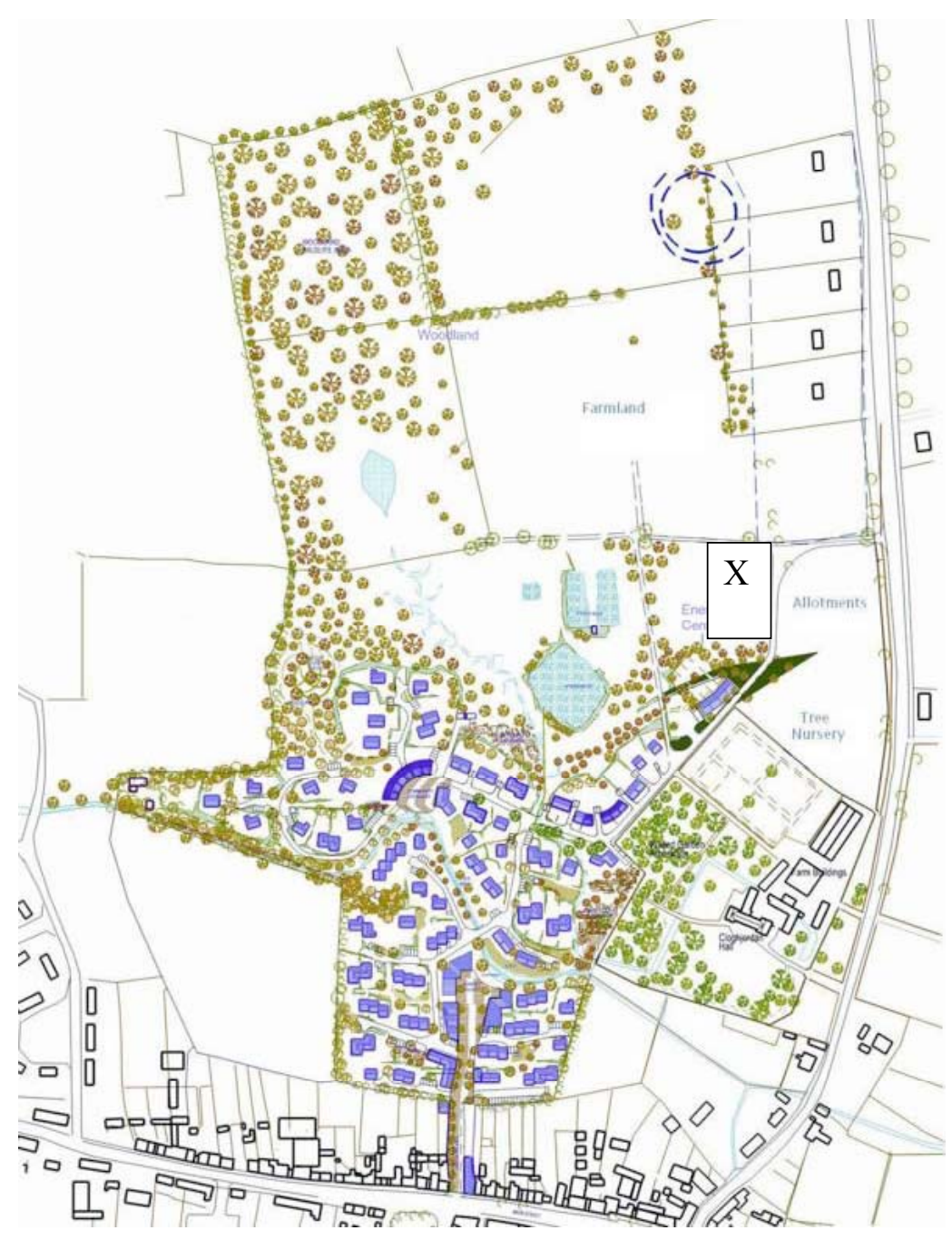

Fig. (7). Schematic of community plan. With solar park site marked with X.

which could prevent sunlight getting to the system and reducing its functionality. To prevent over-shadowing between the row of solar arrays, rows should be kept at a minimum of $4.8 \mathrm{~m}$ apart. The chosen site illustrated in Fig. (7) has been chosen due to its location beside the main energy centre where the boiler is kept. This location is also divided from the main farming area to the north, so interference with food production in the main farming area is kept to a minimum. By positioning the solar arrays in the north east corner of this site, overshading from trees extending from the residential area is minimised. This site also allows for ease of installation of such a project.

\section{PV MARKETS}

Traditionally world energy demands have been met through fossil fuel resource, however, currently these resources are decreasing, while demand due to increased population size and industry, increases, resulting in a world-wide energy crisis. In a bid to reduce our reliance on fossil fuel and to develop a more sustainable energy future a number of new technologies and approaches are being developed. The European Union (EU) has become a forerunner in these developments. This fact is mainly due to the fact that the EU has become the world's largest importer of oil and gas for energy requirements [24]. 2007 seen the EU import 82 percent of its oil and 57 percent of its gas from third-party states [25].

Securing an energy supply, which can be controlled nationally, has led the EU to committing itself to developing a more sustainable future. As of January 2009, the EU has engaged to increase and meet renewable energy targets of $20 \%$ of the total energ consumption, within the EU by 2020 . This objective is set out in the EU's 2020 by 2020 package. This package, published in January 2008 proposes committing the EU to a $20 \%$ reduction in its greenhouse gas (GHG) emissions and to achieving a target of deriving $20 \%$ of the EU's final energy consumption from renewables sources, both by 2020 [25]. The same proposal states that for this objective to be achieved Ireland must target for a share of $16 \%$ of energy from renewable sources in final consumption of energy in 2020, an increase of $12.9 \%$ over the share of renewable energy resources used in energy in 2005.

\section{MARKET DRIVERS}

Ireland, a nation with a limited indigenous fuel resource, coupled with an increase in industry and in population, has 
quickly become reliant on importing a high percentage of its energy requirement. According to Sustainable Energy Ireland (SEI), Ireland in 1990, was able to meet $32 \%$ of its energy requirements with indigenous resources, but has become even more dependent on importing energy resources as energy requirements increased and indigenous supply decreased, resulting in Ireland's import dependency reaching $90 \%$ in 2005 [26]. In a world where supply security is threatened and prices are volatile, we must look towards ways in which our energy demands are either reduced or produced natively in a sustainable manner. This move to sustainable supply will allow Ireland to move away from imported fuels and to reduce its use of native fossils fuels, which are adding to the global problem of climate change. Allowing for Ireland to achieve many legislative targets set out by the EU. The main legislation of concern in this matter is the Energy Performance of Buildings Directive (EPBD). The EU Commission adopted the EPBD into EU law in 2006. In developing the EBPD, the EU Commission identified the importance of buildings and their impact on present and also long-term energy consumption levels. In respect to this the Directive laid down a number of specific measures to ensure that all building in the future would meet EBPD requirements. Many of these requirements are mirrored in the eco-charter set out by the Cloughjordan Development. The passing of the EBPD required all EU governments to but in place the BER certification scheme, which now act as the main method for generating information regarding buildings' energy demand and carbon dioxide emissions.

One of the EU's primary goals is to reduce the consumption and wastage levels of energy. This move, to improve energy efficiency, will provide a useful target in a number of fields including security of supply and in meeting targets in carbon dioxide $\left(\mathrm{CO}_{2}\right)$ reduction, as set out in the Kyoto protocol. With up to $40 \%$ of energy being consumed in buildings [27]. The EU is looking towards ways in which energy, especially for the domestic market can be produced in a sustainable and reliable manner. In response to this the EU has put in place a number of drivers to promote renewable energy policies. These drivers include economic and environmental issues, but also consider social issues, all of, which have the potential ability to produce positive impacts from local through to global scales.

The drivers for renewable energy drivers within the EU, as describe in the 2003, Renewable Energy Policies and Market Developments report are described below.

\section{Economic Drivers}

Security of Supply: The EU's high dependency on importing fossil fuels to meet its high energy demands, has left this society highly vulnerable to price fluctuations. The development of renewable energy sources with in the EU reduces this risk associated with external supply, while also increasing its own socio-economic stability. Another reason for security of supply comes in the realisation that a high percentage of fossil fuel comes from politically unstable areas, (45\% of oil imports come from the Middle East and $40 \%$ of natural gas imports come from Russia).

Leading European Industry: With an encouraging policy, the European companies may increase their market share and be able to take large parts of future world-wide business op- portunities in the renewable energy sector, allowing for Europe to become the leader in renewable energy supplies, thus stimulating the European economy.

Economical Optimisation: Economic optimisation of the energy supply is a major rationale when taking renewable energy options into account. This is especially true when taking into account energy supply to remote or inaccessible areas, where RES often provide a cheaper option that grid extension. Allowing for capital savings to be gained through the use of stand alone or decentralised energy supplies.

\section{Environmental Drivers}

Reducing Emissions: in the case of renewable energy (except biomass), there are no direct emissions from the energy conversion. Generally, the energy is generated from non-emission sources (wave, wind or solar energy). In the case of biomass or waste, emissions do exist, but these are limited according to legislation, providing an opportunity to "significantly reduce anthropogenic GHG's" [28].

Reducing Climate Change: the emissions from biomass and waste are considered to alleviate the environmental pressure because of the closed short carbon cycle. Toxic emissions emerge in the same quantity or even larger quantities compared to fossil fuels, but at least no additional $\mathrm{CO}_{2}$ is emitted into the atmosphere in the form of burnt fossil fuels. The $\mathrm{CO}_{2}$ has been captured before, and would also be released through alternative routes as natural biodegradation or dumping.

\section{Social Drivers}

Employment: with an increase in this industry a number of new employment opportunities will be created, via both direct and indirect sources. This could include employment opportunities in manufacturing and installation of plants, and also in maintenance and fuel provision, in the case of biomass. It is very difficult to assess the impact of renewable energy policy and labour, but it is assumed that the overall effect on the European labour market will be positive with a proceeding penetration of renewable energy sources.

Social-economic cohesion: the renewable energy sector has potential to be developed in areas unattractive to other industry, helping areas which have previously suffered economically to develop and thrive. This may include cultivation of biomass crops in rural areas of development of solar parks in Southern countries, or wind farms in remote areas.

Public support: the subject of renewable energy is alive in Europe. This has developed through a greater public interest in sustainable life-styles, with renewable energy sources being considered an integral part of sustainability.

\section{CURRENT MARKET STATUS}

Traditionally Global Energy Markets shares have been lead by oil and gas production. Oil being the for-runner in this market. However the traditional trends have been evolving to where oil shares have been decreasing steadily over the past two decades, in favour of gas, hydro and renewables. In 2006 the Global Primary Energy Consumption was 15.8 Terawatts (TW). Of this $15.8 \mathrm{TW}$, fossil fuel accounted for $86 \%$ of the energy supply while renewables accounted for only $1 \%$ [29]. As realisation of the fact that fossil fuel 
resources are being exhausted, more and more attention is being given to renewable energy resources. This fact has seen the Renewable Energy Industry expand in recent years. In the twelve-month period between 2007 and 2008, the Renewables Global Status reports that the global power capacity from new renewable energy sources (excluding large hydro) rose by $16 \%$ in 2008 to reach a production capacity of $280,000 \mathrm{MW}$ [30]. From renewable resources, wind and solar power production have received the most attention. Figures released by the Earth Policy Institute in Washington DC, shows that on a Global context, production of PV increased to 3,800 MW world-wide in 2007, up an estimated 50 percent over 2006. Growing by an impressive average of $48 \%$ each year since 2002 , PV production has been doubling every two years, making it the world's fastestgrowing energy source (Brown, 2009). This growth has been attributed to a decrease in costs and prices of production and installation and also an increase in technologies and performance efficiencies. The US Department of Energy has stated that "Advances in technology and economies of scale, along with demand for solutions to global warming, have led photovoltaics to become the most likely candidate to replace nuclear and fossil fuels".

Germany has become the world's greatest consumer of PV electricity. In 2007 Germany consumed nearly 50\% of global solar power production and has been steadily increasing its production capacities. Solar power now meets about 1 percent of Germany's electricity demand, a share that some market analysts expect could reach 25 percent by 2050 .

\section{BARRIERS TO IRISH MARKET}

Currently in Ireland there is no national REFIT scheme available for the generation of PV solar electricity. However an alternative scheme is available for the exportation of PV electricity and this involves the connection of a microgenerator to the ESB network. This scheme, as described by the Electricity Supply Board (ESB), defines microgeneration as a source of electrical energy, which operates parallel to ESB Networks Low Voltage systems, which are rated up to and including:

$6 \mathrm{~kW}$ when the connection is single phase,

$11 \mathrm{~kW}$ when the connection is three phase.

Under this scheme, which started operating in 2009, ESB offers exporters of electricity a tariff of nine 9 cents per $\mathrm{kWh}$ exported. ESB are also offering a further support payment of 10 cents per $\mathrm{kWh}$ for the first 3,000 kWh exported annually. This payment will be made to the first 4,000 microgenerators connected in the next three-years and will be paid over a five-year period. Micro-generation covers small-scale generators where customers can generate their own electricity and export the surplus onto ESB Networks Low Voltage System subject to the above rated maximum output.

Examples of micro-generation technology given by ESB include:

- Wind-power

- Photovoltaic

- Hydro

- $\quad$ Combined heat-and-power (CHP)

\section{MATERIALS AND METHOD}

The Cloughjordan development when completed will comprise of 114 housing units with an average area of 140 square metres, and 16 live-work units averaging 195 squared meters in area. As this development is not yet complete, and at the time of carrying out this project only a number of resident were occupied, all information regarding community demands was obtained by predicting demands. These predicted demands were obtained using information about the structural properties, BER certificates, average sizes and numbers of different units that will be present in the completed development. This information along with information obtained from the NUI Maynooth report, regarding typical monthly energy demands, was used to construct Excel spreadsheets detailing average energy demands per unit per year. These Excel spreadsheets examined each unit type and generated information regarding average size and using the minimum BER certificate of $\mathrm{B} 1$. This $\mathrm{B} 1$ rating has a range of $75 \mathrm{kWh} / \mathrm{m}^{2} / \mathrm{yr}$ to $100 \mathrm{kWh} / \mathrm{m}^{2} / \mathrm{yr}$. To determine the size of the over all system, monthly requirements on each unit type over the demand range were investigated. This was achieved by working out the yearly demand per unit type. To do this the BER rating range was multiplied by the unit area size. These demand ranges are displayed in Table 2 .

Table 2. Demand Range Per Unit Size

\begin{tabular}{|c|c|c|}
\hline Unit size (m2) & $\mathbf{7 5} \mathbf{k W h} / \mathbf{m} \mathbf{2} / \mathbf{y r}$ & $\mathbf{1 0 0 k W h} / \mathbf{m} \mathbf{2} \mathbf{y r}$ \\
\hline \hline 140 & 10500 & 14000 \\
\hline 195 & 14625 & 19500 \\
\hline
\end{tabular}

With the demand range identified, monthly demands were determined, this was achieved using information obtained from the NUI Maynooth report mentioned previously, from which monthly energy percentage demands were identified. These monthly percentages were used to determine the monthly demands for each of the unit typed in this development. This information is displayed in Table 3 below.

With this information generated, it was then possible to determine the area requirements per unit, from which an over all area requirement could be devised. This was achieved through divided into four seasons: Spring (March, April, May), Summer (June, July, August), Autumn (September, October, November) and Winter (December, January, February) and calculating the area required for a $2.10 \mathrm{Wp}$ system, operating at $86 \%$ efficiency without interference of overshadowing. Research carried out on PV systems identifies Kyocera modules to be most economical in terms of money and space, from this producer the Kyocera KD $210 \mathrm{GH}-2 \mathrm{P}$ is preferable. This system will be detailed in greater detail in a following section. To calculate the area requirement, the season with highest energy demands was investigated per unit size. This seasonal demand was investigated, as having the highest demand for the over all yearly requirements, means that in matching the demands during this season, will result in production of excess energy in other seasons, with the possibility of exporting this excess and generating a profit. This investigation looked at the demand range over the B1 BER rating. These demands are shown in Table 4 below. 
Table 3. Breakdown of Monthly Energy Demands for each Unit Type, over B1 BER Rating of $75-100 \mathrm{kWh} / \mathrm{m}^{2}$

\begin{tabular}{|c|c|c|c|c|c|}
\hline Month & $\begin{array}{c}\text { Monthly \% } \\
\text { Demand }\end{array}$ & \multicolumn{2}{|c|}{ Homes } & \multicolumn{2}{|c|}{ Live Work Units } \\
\hline January & 12.61 & 1324.10 & 1765.46 & 1844.28 & 2459.04 \\
\hline February & 11.89 & 1248.19 & 1664.26 & 1738.55 & 2318.07 \\
\hline April & 8.92 & 936.14 & 1248.19 & 1303.92 & 1738.55 \\
\hline May & 6.43 & 674.70 & 899.60 & 939.76 & 1253.01 \\
\hline June & 3.69 & 387.95 & 517.27 & 540.36 & 720.48 \\
\hline July & 3.53 & 371.08 & 494.78 & 516.87 & 689.16 \\
\hline October & 8.27 & 868.67 & 1158.23 & 1209.94 & 1613.25 \\
\hline November & 11.89 & 1248.19 & 1664.26 & 1738.55 & 2318.07 \\
\hline December & 12.37 & 1298.80 & 1731.73 & 1809.04 & 2412.05 \\
\hline Total/yr. & 100.00 & 10500.00 & 14000.00 & 14625.00 & 19500.00 \\
\hline No: Units & & 114 & 114 & 16 & 16 \\
\hline
\end{tabular}

Table 4. Seasonal Demand Ranges Showing Comparisons between Unit Size for B1 BER

\begin{tabular}{|c|c|c|c|c|}
\hline & $\mathbf{1 4 0 m 2} \mathbf{7 5 k W h}$ & $\mathbf{1 4 0 m 2} \mathbf{1 0 0 k W h}$ & $\mathbf{1 9 5 m 2 * 7 5 k W h}$ & $\mathbf{1 9 5 m 2 * 1 0 0 k W h}$ \\
\hline \hline Winter & 3871.08 & 5161.45 & 5391.87 & 7189.16 \\
\hline Spring & 2698.80 & 3598.39 & 3759.04 & 5012.05 \\
\hline Summer & 1146.99 & 1529.32 & 1597.59 & 2130.12 \\
\hline Autumn & 2783.13 & 3710.84 & 3876.51 & 5168.67 \\
\hline
\end{tabular}

From Table 4 it is seen that in this instance the season with the greatest demands is Winter, with a average seasonal demand range of $3871.08-5161.45 \mathrm{kWh} / \mathrm{m}^{2}$ for the smaller housing units of $140 \mathrm{~m}^{2}$ to $5391.87-7189.16 \mathrm{kWh} / \mathrm{m}^{2}$ for the larger live/work units of $195 \mathrm{~m}^{2}$. For comparison between costs to installers, this investigation was carried out on both demands per individual units and for community demands. This allowed for investigations between costs to installers based on either installation of individual systems or installation of a community solar park system. To generate information on community demands, each unit size was multiplied by the number of those specific units in the development. When demands were generated per unit size, a total demand for the B1 BER range was identified by addition of the total demands for each unit size in the lower and higher range values.

From the above table, the overall demand range, shown in bold print has been obtained by addition of the total yearly demand from each unit type within the same BER range. Therefore the total equating to $1,413,000 \mathrm{kWh}$ is obtained by addition of total seasonal demand of both unit types in the $75 \mathrm{kWh} / \mathrm{m} 2 / \mathrm{yr}$. range. Likewise the total equating $1,908,000$ $\mathrm{kWh}$ is obtained by addition of total seasonal demands of both unit types in the $100 \mathrm{kWh} / \mathrm{m} 2 / \mathrm{yr}$. range. Table 5 also shows the community's winter demands as ranging from $527,573.5-703,431.3 \mathrm{kWh}$.

As mentioned previously, to ensure sufficient energy supply through out the year, sufficient energy must be produced during the season with the highest demands. Therefore, to determine the required area of PV panels to sufficiently supply energy, the area requirements for supply winter energy demands was investigated. This involved investigating the potential energy production for Cloughjordan, which was achieved using the EU PVGIS online calculator. This calculator gives the monthly average sum of global irradiation per square meter received by the modules of the given system $(\mathrm{kWh} / \mathrm{m} 2)$. These results are conveyed in Fig. (8) below. From these monthly averages, seasonal potentials for each of the four seasons were calculated. 
Table 5. Community Seasonal and Total Yearly Demands for each Range Scale of B1 BER

\begin{tabular}{|c|c|c|c|c|c|}
\hline & Winter & Spring & Summer & Autumn & Total kWh/yr. \\
\hline \hline $140 \mathrm{~m} 2 * 75 \mathrm{Kwh}$ & 441303.6 & 307662.7 & 130756.6 & 317277.1 & 1197000 \\
\hline $195 \mathrm{~m} 2 * 75 \mathrm{kWh}$ & 86269.88 & 60144.58 & 25561.45 & 62024.1 & 234000 \\
\hline Total & 527573.5 & 367807.2 & 156318.1 & 379301.2 & $\mathbf{1 4 3 1 0 0 0}$ \\
\hline $140 \mathrm{~m} 2 * 100 \mathrm{Kwh}$ & 588404.8 & 410216.9 & 174342.2 & 423036.1 & 82698.8 \\
\hline $195 \mathrm{~m} 2 * 100 \mathrm{kWh}$ & 115026.5 & 80192.77 & 34081.93 & 505734.9 & $\mathbf{1 9 0 8 0 0 0}$ \\
\hline Total & 703431.3 & 490409.6 & 208424.1 & 512000 \\
\hline
\end{tabular}

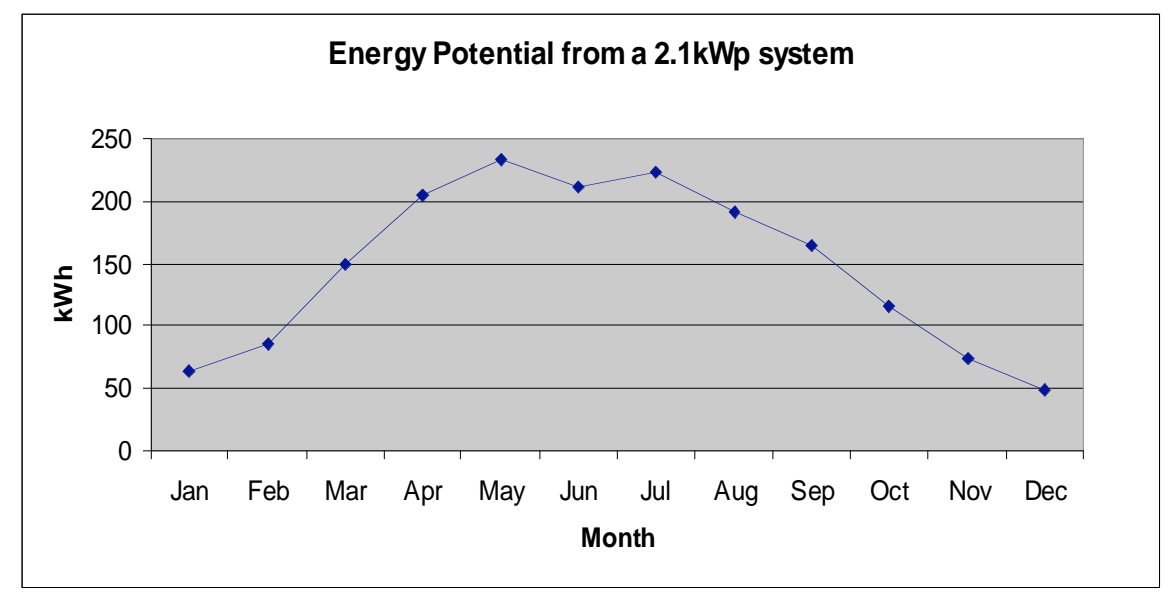

Fig. (8). Average monthly energy potential for a $2.1 \mathrm{kWp}$ system, at Cloughjordan.

Table 6. Seasonal Energy Potential for Cloughjordan

\begin{tabular}{|c|c|c|c|c|}
\hline & Winter & Spring & Summer & Autumn \\
\hline \hline Seasonal Potential $(\mathrm{kWh})$ & 198 & 587 & 626 & 352.8 \\
\hline
\end{tabular}

The above results were generated by entering the geographical co-ordinated for Cloughjordan in to the online calculator and choosing a $2.1 \mathrm{~kW}$ crystalline system. This calculator estimated combined losses form such a system to be $23.0 \%$. From this $12.3 \%$ is estimated to be lost due to transmission, $3.1 \%$ estimated to be lost due to angular reflectance effects and a further $7.6 \%$ estimated to be lost due to temperature [21]. From Fig. (8) it was possible to devise a table depicting the seasonal potential for this system.

\section{RESULTS}

With all the above information generated the next process was to identify the cost and area requirements for such a system. To identify the area requirements the winter demands were divided by the winter potential. These calculations identifies the area as meters squared, and have been carried out for the over all community demands over the B1 BER, and also for each of individual units over the same $\mathrm{BER}$ range. With the area requirements identified, it is then possible to calculate the number of PV panels required and the over all cost of installing a system like this. The area requirements are conveyed in Table 7 , indicating area requirements for individual units and also for the community as a whole.

From Table 7 above it is shown that the smaller units of $140 \mathrm{~m}^{2}$ have an area requirements ranging from $20 \mathrm{~m}^{2}-26$ $\mathrm{m}^{2}$, while the larger live/work units have an area requirement of $27 \mathrm{~m}^{2}-36 \mathrm{~m}^{2}$. While the communal solar park has an area requirement of $2665 \mathrm{~m}^{2}-3553 \mathrm{~m}^{2}$ without spacing, this however will differ when space requirements are calculated to prevent overshadowing.

The PV panels hypothesised for use in this system, the Kyocera KD 210GH-2P, has dimensions of $1500 \times 990 \times 36$ $\mathrm{mm}$, equating to a surface area of $1.485 \mathrm{~m}^{2}$. Research carried out on available PV systems identifies Kyocera modules to be most economical in terms of money and space. To increase the performance of such a system and to reduce space requirements, use of the Kyocera KD $210 \mathrm{GH}-2 \mathrm{P}$ is preferable. This unit has peak yearly output of $210 \mathrm{kWh}$. These poly-crystal modules are suitable for use in residential, public and industrial systems. The technologies employed by this processor produce a highly efficient polycrystalline pho- 
Table 7. Winter Demands and Associated Area Required for Matching Demands

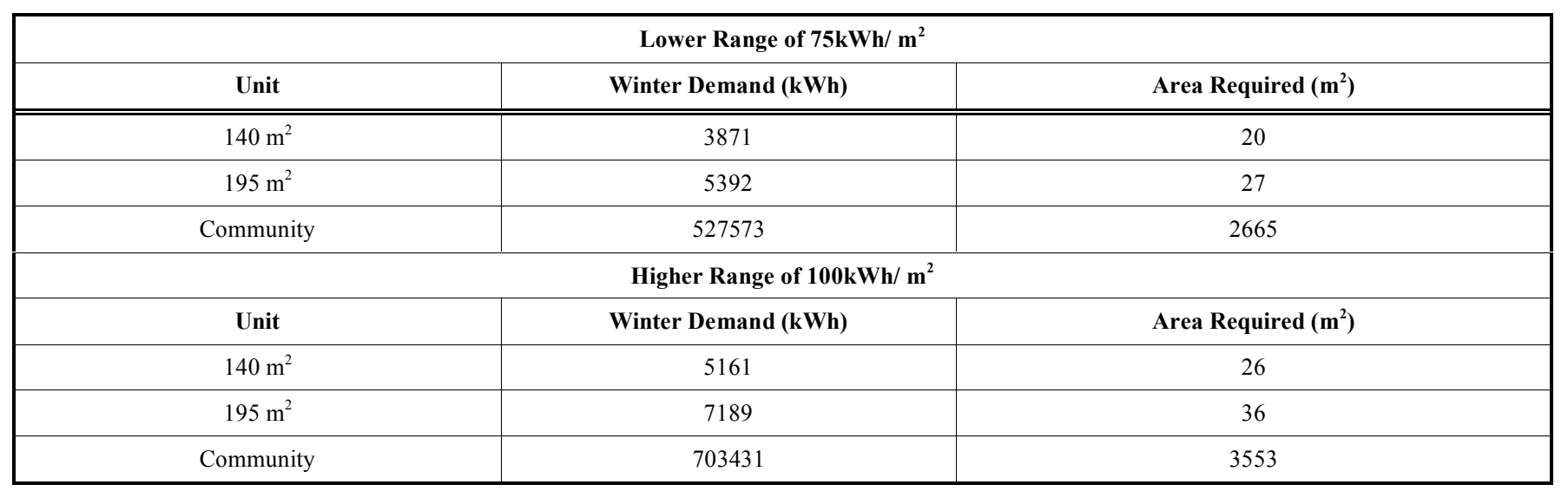

tovoltaic module with conversion efficiency of up to $15 \%$. Modules are constructed to withstand harshest environmental conditions and the entire module is installed in an anodised aluminium frame to provide structural strength and ease of installation. Each module costs $€ 650$.

This information regarding the size and cost of the modules was coupled with the area requirements to generate information on the over all number of modules required and the over all costs, for both individual and communal solar park installations.

Table 8. Number of Modules Required Per Area Requirement, with Associated Costs of these Modules

\begin{tabular}{|c|c|c|}
\hline \multicolumn{3}{|c|}{ Lower Range of $75 \mathrm{kWh} / \mathrm{m}^{2}$} \\
\hline Area Required $\left(\mathrm{m}^{2)}\right.$ & No: of Modules & Cost $(€)$ \\
\hline 20 & 13 & 8450 \\
\hline 27 & 18 & 11700 \\
\hline 2665 & 1794 & 1166100 \\
\hline \multicolumn{3}{|c|}{ Higher Range of $100 \mathrm{kWh} / \mathrm{m}^{2}$} \\
\hline 26 & 17 & 11050 \\
\hline 36 & 24 & 15600 \\
\hline 3553 & 2392 & 1554800 \\
\hline
\end{tabular}

Using the area requirements for the individual units and the communal solar park, it was possible to determine the number of modules required to meet this requirement. This was achieved by dividing the required area by $1.485 \mathrm{~m}^{2}$, the surface area of the modules. The number of modules was then multiplied by $€ 650$, the cost per module, to generate the over all cost for installing the required amount of modules to sufficiently meet winter demands. These results indicate that for the smaller housing units of $140 \mathrm{~m}^{2}$ in the lower demand range of $75 \mathrm{kWh} / \mathrm{m}^{2}, 13$ modules are required at a cost of $€ 8,540$, in this same demand range the larger live/work units require 18 modules, costing $€ 11,700$ in total. For the smaller housing units of $140 \mathrm{~m}^{2}$ in the higher demand range of 100 $\mathrm{kWh} / \mathrm{m}^{2}, 17$ modules are required at a cost of $€ 11,050$, while 24 module are required for the larger live/work units in this same demand range, costing $€ 15,600$. For the development of a communal solar park, the number of modules required ranges from 1794 to 2392 , with total costs of modules equating to $€ 1,166,100$ to $€ 1,554,800$. If these costs were to be covered evenly by the 130 homeowners this would result in a cost range of $€ 8,970$ - $€ 11,960$.

As previously mentioned, the arrays in the communal solar park are to be set out in rows $4.8 \mathrm{~m}$ apart, so to prevent overshadowing. Therefore, to determine the required area for this development the module base length of $0.99 \mathrm{~m}$ and the new width of $4.8 \mathrm{~m}$ must multiply the number of modules required. This calculation gives the surface required to generate power without interference caused by overshadowing. The results for these area requirements are conveyed in Table 9.

Table 9. Area Range in $\mathbf{m}^{2}$ Required for Solar Park Development

\begin{tabular}{|c|c|c|c|c|}
\hline $\begin{array}{c}\text { Modules } \\
\text { Required }\end{array}$ & $\begin{array}{c}\text { Base } \\
\text { Length }\end{array}$ & Width & Area Required $\mathbf{m}^{2}$ & $\begin{array}{c}\text { Area Required } \\
\text { Acres }\end{array}$ \\
\hline \hline 1794 & 0.99 & 4.8 & 8525 & 2.1 \\
\hline 2392 & 0.99 & 4.8 & 11366 & 2.6 \\
\hline
\end{tabular}

With these new area requirements for the development of the solar park, the over all size of the required solar park equates to being in the range of $2.1-2.6$ acres. With the possibility of developing such a project, whereby $100 \%$ of winter energy demands are met using PV modules, this results in production of excess energy during other seasons. Although no scheme is currently in place for large scale generation of PV solar power for export, if this project were to qualify for the REFIT scheme, whereby 19 cents is paid per $\mathrm{kWh}$ for the first 3,000 kWh exported annually, and 9 cents per $\mathrm{kWh}$ over $3,000 \mathrm{kWh}$, this project has the potential to generate a yearly income of approximately $€ 42,402$ 81,815 . These results are conveyed in Table $\mathbf{1 0}$.

Not only has this project the potential to generate a yearly income, the production of PV solar power for this community, will reduce demand on the national energy provider, which currently uses a majority of fossil fuel technologies in the production of energy. Every kWh of renewable energy prevents the production of $0.198 \mathrm{kgs} / \mathrm{CO}_{2}$; this equates to a yearly saving of approximately 283340 - 377785 
Table 10. Seasonal Breakdown of Community Demands for B1 BER, Excess Per Season and Potential Income Per Year

\begin{tabular}{|c|c|c|c|c|c|c|}
\hline Season & Winter & Spring & Summer & Autumn & Total/Yr & Income (€) \\
\hline Demand & 527573 & 367807 & 156318 & 379301 & 1431000 & \\
\hline Excess & 0 & 159766 & 159766 & 148272 & 467805 & 42402 \\
\hline Demand & 703431 & 490410 & 208424 & 505735 & 1908000 & \\
\hline Excess & 0 & 213022 & 495007 & 197696 & 905725 & 81815 \\
\hline
\end{tabular}

Table 11. Seasonal Breakdown of Demands per Individual unit for B1 BER Range, with Excess per Season and Potential Income Per Year

\begin{tabular}{|c|c|c|c|c|c|c|}
\hline \multicolumn{7}{|c|}{ Lower Range of $75 \mathrm{kWh} / \mathrm{m}^{2}$} \\
\hline & Winter & Spring & Summer & Autumn & Total/Yr & Income $(€)$ \\
\hline Demand kWh (house) & 3871 & 2699 & 1147 & 2783 & 10500 & \\
\hline Excess & 0 & 1172 & 2724 & 1088 & 4984 & 749 \\
\hline Demand kWh (live/work unit) & 5392 & 3759 & 1598 & 3877 & 14625 & \\
\hline Excess & 0 & 1633 & 3794 & 1515 & 6942 & 925 \\
\hline \multicolumn{7}{|c|}{ Higher Range of $100 \mathrm{kWh} / \mathrm{m}^{2}$} \\
\hline Demand kWh (house & 5161 & 3598 & 1529 & 3711 & 14000 & \\
\hline Excess & 0 & 1563 & 3632 & 1451 & 6646 & 898 \\
\hline Demand kWh (live/work unit) & 7189 & 5012 & 2130 & 5169 & 19500 & \\
\hline Excess & 0 & 2177 & 5059 & 2020 & 9257 & 1133 \\
\hline
\end{tabular}

$\mathrm{kg} / \mathrm{CO}_{2} / \mathrm{yr}$ from this system. These figures are obtained by multiply the total yearly demand by the conversion factor of $0.198 \mathrm{~kg} / \mathrm{yr}$. of $\mathrm{CO}_{2}$ for every $\mathrm{kWh} / \mathrm{m}^{2} / \mathrm{yr}$.

\section{DISCUSSION AND CONCLUSION}

If individual homeowner were to opt to install individual PV system on their own properties and considering all favourable conditions are met, property owners therefore have the potential to generate an income range from $€ 794-€ 1133$, depending on unit size and which scale range their property falls into. See Table $\mathbf{1 1}$ for the exact breakdown. In this instance of individual systems, $\mathrm{CO}_{2}$ saving are in the range of $148-178 \mathrm{~kg} / \mathrm{CO}_{2} / \mathrm{yr}$ for the smaller house units of $140 \mathrm{~m} 2$ and $183-215 \mathrm{~kg} / \mathrm{CO}_{2} / \mathrm{yr}$. With total community $\mathrm{CO}_{2}$ saving ranging from $283338-377784 \mathrm{~kg} / \mathrm{CO}_{2} / \mathrm{yr}$.

If this project were to qualify for the Micro-generation scheme or similar schemes rewarding the production, the payback period from monies generated from exporting excess energy would be between 19 and 27 years for the development of a solar park, and between 11 and 13 years for individual installations. The lowest payback period is for the installation of the smaller PV system required to generate energy for a house in the lower scale of the B1 BER. The highest payback period is for the installation of the larger PV system required to generate energy for a live/work in the higher scale of the B1 BER.

Although the development of a communal solar park, may result in increased expenses, occurring due to the needs of additional equipment, such a frames, inverters and meters to record individual household usage, this system may work out to be most feasible in terms of energy production and
CO2 savings. If this system were to be installed, a fair costing procedure, whereby cost incurred to those in smaller units is lower that those in the larger, more energy demanding units. This should make the project more attractive to those in smaller units, who are in majority in this development.

The development of a centralised solar park, whereby an on-site mini grid is the main source of energy for this ecofriendly community allows for adherence to the eco-friendly ethos governing this sustainable community development. Although this development requires a significantly large area of land, in the range of $2.1-2.6$ acres, the potential benefits receivable from such a development out weigh this loss of lands. By replacing this community's energy demand with renewable energy, up to $283-377 \mathrm{~T} / \mathrm{CO}_{2} /$ are saved each year.

\section{ACKNOWLEDGEMENT}

This research was co-authored by Dr Ger Devlin, who is funded under the Science Foundation Ireland Charles Parsons Award 06/CP/E001www.sfi.ie.

\section{CONFLICT OF INTEREST}

None Declared.

\section{REFERENCES}

[1] European Commission on Energy. EU Crude oil imports: Market observatory. http://ec.europa.eu/energy/observatory/oil/import_ex-port en.htm (accessed: 07/10/09).

[2] Campoccia, A.; Dusonchet, L.; Telaretti, E.; Zizzo, G. Comparative analysis of different supporting measures for the production of electrical energy by solar PV and Wind systems: Four representative European cases. Solar Energy., 2009, 83, 287-297. 
[3] Nomisma Energia. The new renewable sources for electricity in Europe. http://www.cittaitalia.org/images/file/Citta.doc/Rapporto_NE_EnergiaRinnovabile.pdf?phpMyAdmin $=95 \mathrm{af3} 1 \mathrm{fc} 7 \mathrm{e} 586 \mathrm{~d}-$ 80 7 - $\bar{d} 64$ a36f07b8b6 (accessed: 02/03/10)

[4] Frenzal, J.; Barbeck, A.; Grempmeier, K.; Bender. B. Photovoltaics. In CRES, ZERU \& Ecole des Mines de Paris, ed. Guidebook on the Renewable Energy Systems Power Generation Technologies. Athens. European Commission, 2001; pp. 29-31.

[5] Solarserver. Solar Radiation. http://www.solarserver.de/lexikon/sonneneinstrahlung-e.html (accessed: 01/03/10).

[6] Sustainable Energy Ireland (SEI). Solar Photovoltaic (PV) Systems. What is Solar Power http://www.sei.ie/Renewables/Solar_Energy/\#SolarPhoto (accessed 20/10/09).

[7] Sustainable Energy Ireland. Energy Policy Statistical Support Unit. In: Energy in the Residential Sector. http://www.sei.ie/News_Events/Press_Releases/Energy_in_the_Residential_Sector_FNL.pdf (accessed: 05/11/09).

[8] Loughlin, James, From telephone conversion with coolpower employee, 08/04/10, 2010.

[9] US Department of Energy. Solar Energy Technologies Program. http://www1.eere.energy.gov/solar/solar_glossary.html (accessed: 29/10/09).

[10] Goetzberger, A.; Hoffman, V.U. Photovoltaic Solar Energy Generation; Springer: Berlin, 2005.

[11] Cardon, F.; Gomes, W.P.; Dekeyser, W. Photovoltaic and Photoelectrochemical Solar Energy Conversions. Plenum Press: New York, 1981.

[12] Bonham-Carter, C.; Cheshire, D. Solar Power Feasibility Study Sustainable Eastside Faber Maunsell: Birmingham, 2003.

[13] Saveenergyuk.com. Solar Lighting and Electricity. Solar PV Systems. http://www.saveenergyuk.com/solar_lighting_electricity.htm (accessed: 01/03/10).

[14] Met Éireann. Sunshine in Ireland. http://www.met.ie/climate/sunshine.asp. (accessed: 02/03/10).

[15] Community Climate Change Consortium in Ireland. Projections. http://www.c4i.ie/index.php?page=projection.html (accessed: 10/0$3 / 10)$.

[16] Solarserver. Developments in Germany rise interest in solar power alternatives abroad. http://www.solarserver.de/solarmagazin/solarreport_0407_e.html (accessed: 21/02/10).
[17] Photovoltaic Geographical Information System (PVGIS). Performance of Grid-connected PV. http://re.jrc.ec.europa.eu/pvgis/apps4/pvest.php (accessed: 13/11/09).

[18] Sustainable Energy Authority of Ireland. Dwelling Energy Assessment Procedure (DEAP) 2008 Edition. Version 3.0. SEA: Glasnevin, Dublin 9, 2008.

[19] Building Energy Rating. http://www.energy-rating.ie/chart.html (accessed: 12/04/10).

[20] Liu, X.; Sweeney, J. Impacts of Climate Change on Energy Demand in Greater Dublin Region, Ireland, The 20th Conference on Climate variability and Change, New Orleans, U.S.A., January 20 24,2008

[21] Alsema, E.A.; de Wild Scholten, M.; Fthenakis, V.M. In Environmental Impacts Of Pv Electricity Generation - A Critical Comparison Of Energy Supply Options, 21st European Photovoltaic Solar Energy Conference, Barcelona, Spain, 2006.

[22] SolarBuzz LLC. Solar Energy Industry Statistics: Growth. $\mathrm{http}: / /$ solarbuzz.com/facts-and-figures/markets-growth/marketgrowth (accessed: 10/02/10).

[23] The Associated Press. Low-carbon economy proposed for Europe World Environmental News. http://www.msnbc.msn.com/id/16560106/\#storyContinued (accessed: 7/10/09).

[24] Sustainable Energy Ireland. Security of Supply in Ireland 2006 Energy Policy Statistical Support Unit: Cork, Ireland, 2006.

[25] Pérez-Lombard, L.; Ortiz, J.; Pout, C. A review on buildings energy consumption information. Energ Build, 2008, 40 (3), 394-398.

[26] Devlin, G. Role of Bio-fuels in management of Climate Change. UCD Lecture notes- Advanced Bio-fuels. UCD. Dublin, 2009.

[27] International Energy Agency. World Consumption of Primary Energy by Type and Selected Country Groups 1980 - 2006. http://www.eia.gov/iea/wecbtu.html (accessed: 27/01/10).

[28] REN21. Renewables Global Status Report. Energy Transformation Continues Despite Economic Slowdown. http://www.globalbioenergy.org/uploads/media/0905_REN21_-_GSR_2009_-_update.pdf (accessed: 02/02/10).

[29] Brown, L. Plan B 4.0: Mobilizing to Save Civilization,' $4^{\text {th }}$ ed.; W.W. Norton \& Company: New York, 2009.

[30] Antaris Solar. Fotovoltaik Shop. Fotovoltaik-Module. http://ww-w.fotovoltaikshop.net/artikel-0-100-0-2500-50.html (accessed: $10 / 04 / 10)$.

Received: May 29, 2011

Revised: June 18, 2011

Accepted: June 28, 2011

(C) Flood et al.; Licensee Bentham Open.

This is an open access article licensed under the terms of the Creative Commons Attribution Non-Commercial License (http://creativecommons.org/licenses/by-nc/3.0/) which permits unrestricted, non-commercial use, distribution and reproduction in any medium, provided the work is properly cited. 